\title{
Working hours and health behaviour among nurses at public hospitals ${ }^{1}$
}

\author{
Juliana da Costa Fernandes ${ }^{2}$ \\ Luciana Fernandes Portela ${ }^{3}$ \\ Lúcia Rotenberg ${ }^{3}$ \\ Rosane Harter Griep ${ }^{4}$
}

Objective: to analyse the differences between genders in the description in the professional, domestic and total work hours and assess its association with health-related behaviour among nurses. Methods: this is a transversal study carried out in 18 different public hospitals in the municipality of Rio de Janeiro. The data collection procedure was based on questionnaires. All nurses working with assistance were considered eligible $(n=2,279)$. Results: men and women showed significant differences in relation to working hours. The female group showed longer domestic and total work hours when compared to the group of men. In contrast, the number of hours spent on professional work was higher among men. For the women, both the professional hours and total work hours were often associated with excessive consumption of fried food and also coffee, lack of physical exercise and also the greater occurrence of overweight and obesity. Conclusion: both the professional hours and the domestic work hours need to be taken into account in studies about health, self-care and also the care provided within the context of nursing workers, particularly among women. The results add weight to the need for actions for health promotion in this occupational group and the importance of assessing the impact of long working hours on the health of workers.

Descriptors: Nurses, Male; Work Hours; Life Style; Health; Self Care.

\footnotetext{
${ }^{1}$ Supported by Fogarty International Center, Award Number D43TW000640 and by Fundação Carlos Chagas Filho de Amparo à Pesquisa do Estado do Rio de Janeiro (FAPERJ), process \# E-26/111.554/2008.

${ }^{2}$ Student of specialization in Health Public, Instituto Oswaldo Cruz, Fundação Oswaldo Cruz (FIOCRUZ), Rio de Janeiro, RJ, Brazil.

${ }^{3} \mathrm{PhD}$, Researcher, Instituto Oswaldo Cruz, Fundação Oswaldo Cruz (FIOCRUZ), Rio de Janeiro, RJ, Brazil.

${ }^{4} \mathrm{PhD}$, Adjunct Professor, Instituto Oswaldo Cruz, Fundação Oswaldo Cruz (FIOCRUZ), Rio de Janeiro, RJ, Brazil.
} 


\section{Introduction}

Among the transformations that have occurred over the last few decades in the labour market, we mention the increase in the number of hours worked, a phenomenon that has been observed in several countries ${ }^{(1-2)}$. The long working hours have a negative effect both on professional life and also on the social and family life of the individuals affected $(1,3)$ Difficulties in social relationships and personal activities ${ }^{(1,3)}$, as also the lack of time for leisure pursuits and health care, are often mentioned as being related to long working hours ${ }^{(1,3-4)}$ Thus, long working hours have been associated to several illnesses and symptoms, including bouts of depression, high blood pressure, muscular and skeletal problems, gastrointestinal disorders, stress and fatigue ${ }^{(4-5)}$, and have also been linked to behaviour patterns that are inappropriate for good health, such as a greater consumption of alcohol, cigarette smoking, reduction in the quantity of physical exercise, and an inadequate standard of sleep or other sleep disorders ${ }^{(5-6)}$

The regulation of the working hours in the nursing profession in Brazil occurs by legislation that sets the weekly working hours at between thirty and forty hours per week(7). In hospitals, the working hours are organised on a shift system, with 12 hours of continuous work and then either 36 or 60 hours off(3,5) These working hours make it possible to fit in more than one professional employment, which is often reflected in extremely long and tiring professional working stints ${ }^{(5,8)}$. Together with these factors, the prevalence of females in these professions ${ }^{(1,3,8)}$ means a need to also weigh in the domestic workload and also its interaction with professional employment when assessing the impact that the working hours have on health, as shown in other studies $^{(3,5,8)}$ However, when considering the work within the context of the nursing profession, it is important to stress that the influence of the long working hours affects not only the health of the nursing professionals but also the standard of the nursing care ${ }^{(1)}$.

In Brazil, there are few studies that appraise the association between long professional and domestic work hours and the health aspects within the nursing profession ${ }^{(1,3,9)}$. In relation to the work provided by the nurses, it is important to consider the aspects related to the complexity of the assigned responsibilities of these professionals in the systematic organisation of the work, that requires concentration, alertness, quick action, quality in carrying out the tasks, both planned and unexpected, management of work shift, leadership and also supervision of the general nursing work, among other tasks ${ }^{(2,5)}$. Another shortage in specialised literature is related to the assessment of gender differences in the association between work hours and health aspects.

Thus, the aims of the presented study were to analyse gender differences in the professional and domestic work hours, and also to appraise their association with behaviour patterns related to health among nurses at major hospitals in the city of Rio de Janeiro.

\section{Methods}

The presented article uses data from the Study of Nurses' Health. This is an epidemiological sectional study, carried out in the eighteen most important public hospitals in the municipality of Rio de Janeiro, Brazil, with the data collection having been executed between 2010 and 2011. All nurses working in nursing care in these hospitals were invited to participate in the research. Out of the total universe of 3,904 eligible subjects, 3,229 ( $82.7 \%$ of the total) decided to join the study. For the analyses of the present study, we only considered the data for those individual subjects who said that their professional working hours corresponded to the usual number of hours worked. The final population had 2,279 workers.

The collection of data was based on a multidimensional questionnaire filled in by the worker himself or herself, including information about social and demographical characteristics, professional and domestic work, and general issues about health. The instrument for collection was drawn up based on previous studies with nursing teams ${ }^{(1,3)}$ and improved through five rounds of pre-tests with some 30 nurses. A team of trained professionals was responsible for inviting the workers to participate in the study, explaining the voluntary character of their participation in this research and also for reading the free and informed consent form. After signing the consent form, the questionnaire was handed over to the participant and then a date was set for the return thereof. Data collection was performed between March 2010 and December 2011.

The exposure variables were professional work hours, domestic work hours and total work hours, calculated by adding the number of hours dedicated to professional work and to domestic work. The professional work hours refers to the usual number 
of hours dedicated to professional activities during the week immediately preceding the filling-in of the questionnaire, using the cut-off point of 40 hours of work per week, which is the limit set by the legislation that regulates the nursing profession in Brazil(7) In the case of domestic and total work hours, the cut-off points used represent the median of the distribution, calculated separately for each gender. In this way, different cut-off values were adopted for men and women. In the case of women, we considered $17 \mathrm{~h}$ and $76 \mathrm{~h}$ for domestic and total work hours, while for the men the values here used were $10 \mathrm{~h}$ and $72 \mathrm{~h}$ respectively.

The outcome of interest is characterised by behaviours and variables related to health: consumption of fried foods (low: never/up to 3 times a month, or excessive: 1 to 7 times a week); consumption of fruit and vegetables (appropriate: 1 to 7 times a week, or insufficient: never/up to 3 times a month); body mass index (BMI), which is based on the self-reported weight and height (ideal: $\leq 24.9$, or overweight/obese: $\geq 25.0$ ); physical exercise (yes or no), smoking (non-smokers or smokers/former smokers); sleep pattern ( $\geq 8 \mathrm{~h}$ or $<8 \mathrm{~h}$ per night) and coffee consumption (low consumption or moderate/excessive consumption: $\geq 200 \mathrm{ml}$ ).

The association between the exposure variables and outcomes was tested through multivariate logistic regression analysis, with results presented as odds ratio and respective confidence intervals of $95 \%{ }^{(10)}$. The results of the regression refer to the crude association between the exposure to long work times and the outcome variables, and to the association adjusted by potential confounders, such as: income, age, marital status, work schedules, type of contract, and also the educational level.

This study was approved by the Ethics Committee of the Oswaldo Cruz Foundation (472/08) and also by the hospitals where the research has been carried out.

\section{Results}

Data analysis referred to a total of 1,981 (87.3\%) women and 298 men. Compared to the female nurses, the male nurses showed less healthy habits: they did less physical exercise as a leisure activity, reported being smokers more often, and also mentioned greater consumption of alcoholic beverages, coffee and fried foods, lower consumption of fruit and vegetables. Besides, they were more often classified as overweight and obese (Table 1).
Table 1 - description of nurses at public hospitals in the Municipality of Rio de Janeiro, according to healthrelated behaviour patterns, by gender. Rio de Janeiro, RJ, Brazil, 2012.

\begin{tabular}{|c|c|c|c|}
\hline \multirow[t]{2}{*}{ Characteristics } & $\begin{array}{c}\text { Lady } \\
\text { Nurses } \\
(n=1981)\end{array}$ & $\begin{array}{c}\text { Male } \\
\text { Nurses } \\
(n=298)\end{array}$ & \multirow[t]{2}{*}{ p-value* } \\
\hline & n (\%) & n (\%) & \\
\hline $\begin{array}{l}\text { Consumption of fruit and } \\
\text { vegetables }\end{array}$ & & & 0.046 \\
\hline Adequate & $1,613(57.7)$ & $213(52.5)$ & \\
\hline Low & $1,182(42.3)$ & $193(47.5)$ & \\
\hline Consumption of fried foods & & & 0.019 \\
\hline Low & $1,149(41.1)$ & $142(35.0)$ & \\
\hline Moderate and excessive & $1,646(58.9)$ & $264(65.0)$ & \\
\hline $\begin{array}{l}\text { Consumption of alcoholic } \\
\text { beverages }\end{array}$ & & & $<0.001$ \\
\hline No & $1,083(39.0)$ & $110(27.3)$ & \\
\hline Yes & $1,692(61.0)$ & $293(72.7)$ & \\
\hline Coffee Consumption & & & 0.001 \\
\hline Low consumption & $1,579(80.8)$ & $213(72.4)$ & \\
\hline $\begin{array}{l}\text { Moderate or excessive } \\
\text { consumption }\end{array}$ & 375 (19.2) & $81(27.6)$ & \\
\hline Cigarette Smoking & & & 0.011 \\
\hline Non-smokers & $2,139(76.3)$ & $285(70.5)$ & \\
\hline Former or current smokers & $663(23.7)$ & $119(29.5)$ & \\
\hline Sleep & & & 0.274 \\
\hline 8 hours or more & $1,033(37.3)$ & $137(34.4)$ & \\
\hline Less than 8 hours & $1,740(62.7)$ & $261(65.6)$ & \\
\hline Physical activity as leisure & & & $<0.001$ \\
\hline Yes & 847 (49.1) & $170(41.8)$ & \\
\hline No & $1,945(50.9)$ & $237(58.2)$ & \\
\hline Body Mass Index (BMI) & & & $<0.001$ \\
\hline Low to normal & $1,314(49.1)$ & $114(29.8)$ & \\
\hline Overweight or Obesity & $1,360(50.9)$ & $271(70.2)$ & \\
\hline
\end{tabular}

*Pearson chi-square test ${ }^{(10)}$

The men reported longer professional work hours than women, but in the case of domestic work hours, the figure reported by female nurses is 9 hours longer than that for male nurses ( $p<0.001$ ). Thus, the time dedicated to domestic chores and to professional work can be reflected in the longer total work hours for women when compared to men (Table 2).

Table 2 - Distribution of the nurses in public hospitals of the Municipality of Rio de Janeiro, according to the average length of professional, domestic, and total work hours, by gender. Rio de Janeiro, RJ, Brazil, 2012

\begin{tabular}{lccc}
\hline \multicolumn{1}{c}{$\begin{array}{c}\text { Weekly } \\
\text { number of } \\
\text { hours worked }\end{array}$} & $\begin{array}{c}\text { Lady Nurses } \\
(\mathbf{n = 1 , 9 8 1 )}\end{array}$ & $\begin{array}{c}\text { Male Nurses } \\
(\mathbf{n = 2 9 8})\end{array}$ & p-value* \\
\cline { 2 - 3 } & Mean (SD) & Mean (SD) & \\
\hline Professional & $55.8(20.6)$ & $61.4(21.6)$ & $<0.001$ \\
$\begin{array}{l}\text { Domestic } \\
\begin{array}{l}\text { Total } \\
\text { (professional }+\end{array}\end{array}$ & $21.4(17.7)$ & $12.7(12.0)$ & $<0.001$ \\
domestic) & $77.1(24.5)$ & $73.7(23.2)$ & 0.035 \\
\hline
\end{tabular}

*ANOVA test ${ }^{(10)}$ 
In Table 3, we see the crude and adjusted associations in the women's group. No significant associations have been detected between the domestic work hours and the assessed outcomes in the adjusted analysis. Both the professional and the total working hours have been strongly linked to the moderate or excessive consumption of fried foods, the moderate to high consumption of coffee, the lack of physical exercise, the greater occurrence of overweight or obesity, and shorter sleeping time, after adjustments for confounders.
Among men, few associations were detected between work hours and the outcomes of interest. The only variable to be significantly associated to the professional and to total work hours has been the lack of physical activities. The chance of not taking any physical exercise is about twice among those considered as having extensive professional and total work hours (respectively $\mathrm{OR}=2.37$; CI95\%=1.24-4.53 and OR=2.18; CI95\%=1.23-3.85). In addition, among the men who have reported an extensive total of work hours, a lower consumption of fried foods was observed (Table 4).

Table 3 - Association between domestic, professional and total work hours related to health, among nurses at public hospitals of the municipality of Rio de Janeiro, crude and adjusted odds ratios (OR) and respective confidence intervals at 95\% (CI95\%). Rio de Janeiro, RJ, Brazil, 2012

\begin{tabular}{|c|c|c|c|c|c|c|}
\hline \multirow{3}{*}{$\begin{array}{l}\text { Outcome } \\
\text { variables }\end{array}$} & \multicolumn{6}{|c|}{ Exposure Variables } \\
\hline & \multicolumn{2}{|c|}{ Domestic Working Hours } & \multicolumn{2}{|c|}{ Professional Working Hours } & \multicolumn{2}{|c|}{ Total Working Hours } \\
\hline & CR (Cl95\%) & CRaj $^{*}(\mathrm{Cl} 95 \%)$ & CR (Cl95\%) & $\mathrm{CRaj}^{*}(\mathrm{Cl} 95 \%)$ & CR (Cl95\%) & $\mathrm{CRaj}^{*}(\mathrm{Cl} 95 \%)$ \\
\hline \multicolumn{7}{|l|}{$\begin{array}{l}\text { Consumption of fruit and } \\
\text { vegetables }\end{array}$} \\
\hline Adequate & 1 & 1 & 1 & 1 & 1 & 1 \\
\hline Excessive & $0.76(0.64-0.89)$ & $0.89(0.75-1.07)$ & $1.25(1.00-1.55)$ & $1.14(0.901 .44)$ & $0.88(0.72-1.21)$ & $0.96(0.78-1.18)$ \\
\hline \multicolumn{7}{|l|}{ Consumption of fried foods } \\
\hline Low & 1 & 1 & 1 & 1 & 1 & 1 \\
\hline Moderate/Excessive & $0.88(0.74-1.03)$ & $1.01(0.84-1.20)$ & $1.53(1.23-1.90)$ & $1.36(1.08-1.70)$ & $1.21(0.99-1.07)$ & $1.25(1.02-1.53)$ \\
\hline \multicolumn{7}{|l|}{$\begin{array}{l}\text { Consumption of alcoholic } \\
\text { beverages }\end{array}$} \\
\hline No & 1 & 1 & 1 & 1 & 1 & 1 \\
\hline Yes & $0.92(0.78-1.09)$ & $0.92(0.77-1.10)$ & $1.08(0.87-1.34)$ & $1.13(0.90-1.41)$ & $0.95(0.78-1.16)$ & $0.96(0.78-1.18)$ \\
\hline \multicolumn{7}{|l|}{ Coffee Consumption } \\
\hline None / Low consumption & 1 & 1 & 1 & 1 & 1 & 1 \\
\hline Moderate or High & $1.19(0.93-1.52)$ & $1.05(0.81-1.31)$ & $1.52(1.13-1.87)$ & $1.80(1.32-2.45)$ & 1.45 (1.13-1.89) & $1.41(1.09-1.83)$ \\
\hline \multicolumn{7}{|l|}{ Smoking } \\
\hline Non-Smoker & 1 & 1 & 1 & 1 & 1 & 1 \\
\hline Smoker or ex-smoker & $1.23(1.01-1.49)$ & $1.00(0.81-1.24)$ & $0.90(0.70-1.15)$ & $1,22(0.93-1.60)$ & $1.08(0.86-1.36)$ & $1.10(0.86-1.40)$ \\
\hline \multicolumn{7}{|l|}{ Sleep } \\
\hline Over 8 hours & 1 & 1 & 1 & 1 & 1 & 1 \\
\hline Up to 8 hours & $1.16(0.98-1.38)$ & $1.04(0.87-1.25)$ & $1.18(0.95-1.47)$ & $1.30(1.03-1.64)$ & $1.27(1.03-1.55)$ & $1.28(1.03-1.58)$ \\
\hline \multicolumn{7}{|l|}{ Physical Activity } \\
\hline Yes & 1 & 1 & 1 & 1 & 1 & 1 \\
\hline No & $1.24(1.03-1.48)$ & $1.17(0.98-1.44)$ & $1.34(1.00-1.68)$ & $1.36(1.07-1.72)$ & $1.36(1.10-1.68)$ & $1.35(1.08-1.69)$ \\
\hline \multicolumn{7}{|l|}{ Body Mass Index (BMI) } \\
\hline Ideal & 1 & 1 & 1 & 1 & 1 & 1 \\
\hline Overweight or obesity & $1.47(1.24-1.74)$ & $1.17(0.97-1.40)$ & $1.05(0.85-1.31)$ & $1.26(1.00-1.59)$ & 1.59 (1.30-1.93) & $1.51(1.23-1.87)$ \\
\hline
\end{tabular}

*Adjusted for age, marital status, type of contract, work schedule, educational level and income. 
Table 4 - Association between domestic, professional and total work hours and health-related behaviour among nurses in public hospitals in the municipality of Rio de Janeiro, crude and adjusted odds ratios (ORs) and respective confidence intervals at 95\% (CI95\%), Rio de Janeiro, RJ, Brazil, 2012

\begin{tabular}{|c|c|c|c|c|c|c|}
\hline \multirow{3}{*}{ Outcome Variables } & \multicolumn{6}{|c|}{ Exposure Variables } \\
\hline & \multicolumn{2}{|c|}{ Domestic Working Hours } & \multicolumn{2}{|c|}{ Professional Working Hours } & \multicolumn{2}{|c|}{ Total Working Hours } \\
\hline & CR (CI95\%) & CRaj $^{*}(\mathrm{Cl} 195 \%)$ & CR (Cl95\%) & CRaj* (CI95\%) & CR (Cl95\%) & CRaj* (Cl95\%) \\
\hline \multicolumn{7}{|l|}{$\begin{array}{l}\text { Consumption of fruit and } \\
\text { vegetables }\end{array}$} \\
\hline Adequate & 1 & 1 & 1 & 1 & 1 & 1 \\
\hline Excessive & $0.84(0.54-1.32)$ & $0.88(0.55-1.41)$ & $0.98(0.54-1.80)$ & $0.84(0.44-1.60)$ & $1.55(0.38-1.94)$ & $1.12(0.64-1.96)$ \\
\hline \multicolumn{7}{|l|}{ Consumption of fried food } \\
\hline Low & 1 & 1 & 1 & 1 & 1 & 1 \\
\hline Moderate/Excessive & $0.69(0.44-1.11)$ & $0.71(0.44-1.16)$ & $0.53(0.27-1.04)$ & $0.45(0.22-0.92)$ & $0.76(0.45-1.29)$ & $0.66(0.37-1.18)$ \\
\hline \multicolumn{7}{|l|}{$\begin{array}{l}\text { Consumption of alcoholic } \\
\text { beverages }\end{array}$} \\
\hline No & 1 & 1 & 1 & 1 & 1 & 1 \\
\hline Yes & $0.72(0.43-1.21)$ & $0.72(0.42-1.22)$ & $0.73(0.36-1.46)$ & $0.74(0.36-1.52)$ & $0.67(0.37-1.18)$ & $0.71(0.38-1.30)$ \\
\hline \multicolumn{7}{|l|}{ Consumption of Coffee } \\
\hline No or low consumption & 1 & 1 & 1 & 1 & 1 & 1 \\
\hline Moderate or High & $0.79(0.44-1.42)$ & $0.70(0.38-1.30)$ & $1.54(0.74-3.19)$ & $1.72(0.81-3.66)$ & $1.20(0.67-2.16)$ & $1.13(0.62-2.10)$ \\
\hline \multicolumn{7}{|l|}{ Smoking } \\
\hline Non-smoker & 1 & 1 & 1 & 1 & 1 & 1 \\
\hline $\begin{array}{l}\text { Ex-smoker or current } \\
\text { smoker }\end{array}$ & $1.23(0.76-2.00)$ & $1.25(0.75-2.10)$ & $0.48(0.26-0.91)$ & $0.55(0.28-1.07)$ & $0.50(0.28-0.89)$ & $0.55(0.30-1.02)$ \\
\hline \multicolumn{7}{|l|}{ Sleep } \\
\hline More than 8 hours/day & 1 & 1 & 1 & 1 & 1 & 1 \\
\hline Up to 8 hours/day & $0.75(0.47-1.20)$ & $0.71(0.43-1.16)$ & $0.71(0.36-1.40)$ & $0.72(0.36-1.47)$ & $0.71(1.41-1.23)$ & $0.58(0.32-1.06)$ \\
\hline \multicolumn{7}{|l|}{ Physical Activity } \\
\hline Yes & 1 & 1 & 1 & 1 & 1 & 1 \\
\hline No & $1,08(0,69-1,71)$ & $0,99(0,62-1,59)$ & $1,95(1,06-3,59)$ & $2,37(1,24-4,53)$ & $2,21(1,29-3,78)$ & $2,18(1,23-3,85)$ \\
\hline \multicolumn{7}{|l|}{ Body Mass Index (BMI) } \\
\hline Ideal & 1 & 1 & 1 & 1 & 1 & 1 \\
\hline Overweight or obese & $0.93(0.56-1.53)$ & $0.90(0.54-1.50)$ & $0.88(0.44-1.75)$ & $0.87(0.43-1.75)$ & $1.08(0.88-2.84)$ & $1.59(0.85-2.96)$ \\
\hline
\end{tabular}

*Adjusted by age, marital status, type of employment relationship, work schedule, educational level and income.

\section{Discussion}

The results revealed differences between the genders, showing that groups with specific characteristics are set up. Even though the professional work hours are longer for men, the women have longer domestic work hours and also longer total work hours. For the female group, both the professional and the total work hours show themselves to be significantly associated to the health-related behaviour patterns that have been appraised. Compared to the nurses that have had less professional and total work hours, those with longer time periods spent working are more likely not to carry out physical exercise as a leisure pursuit, on a regular basis. In addition, those with long professional work weeks have a lower consumption of fried food, when compared to those with less working hours.

As already recognised ${ }^{(1,3,11)}$, nursing is a profession in the health area with a strong presence of the distaff gender, being considered as a kind of "female ghetto"(11), as well as the flexible structure of working hours, which makes it possible to conciliate with working at home. It is also possible to establish a relationship with the social growth of these women, as for this group work becomes a source of income and also a kind of life activity that is both personal and professional(1,3,12-13).

Akin to the results shown by another study with nursing teams ${ }^{(8)}$, it was also observed that men worked more in relation to remunerated work, when compared to women. However, the total work hours of men is less, due to reduced responsibilities in domestic work as split between them. On studying the impact of work on the female group, domestic working hours should be weighed in as an important factor, as even with this exit from the "home" towards the formal labour market, women continue to be the main parties responsible for 
the tasks in the home ${ }^{(1,3,8)}$. Some studies $^{(8,14)}$ show that the overload generated by double exposure to work (domestic work and professional employment) has been associated with factors that could be harmful for the health of the workers. However, domestic work may not be seen as damage or something arduous to carry out, and can actually be a source of pleasure for some women, as it results in more time spent with the family and would be a certain compensation for negative aspects of professional employment ${ }^{(15)}$. The female workers in the nursing field carry out extensive activities in the labour environment and this results in longer professional work hours and even the accumulation of two jobs to ensure a better salary ${ }^{(3,8,13)}$. It is thus possible to perceive the influence of the place of work and also the organisation thereof, with direct or indirect action upon the psychic and physical maladjustments of the worker, which can be converted into the failure to comply with the basic needs of professionals, and may also be a factor that contributes to the lack of self-care ${ }^{(13)}$, which could in turn explain the impact that the working hours within the female segment of the population has on such behaviour patterns. Another important item to consider is that often the women are the only breadwinner in the family(11) and hence become much more demanding in compliance and dedication at their professional activities, so as to meet all the needs of their dependants.

The scarcity of free time could explain the lack of physical exercise. The results from some studies $^{(3,16-17)}$ show that nursing professionals ascribe the lack of physical activities to lack of time, which confirms the findings of the present article.

The association between high consumption of fried foods and long work hours in the feminine group is coherent to what has been observed in other

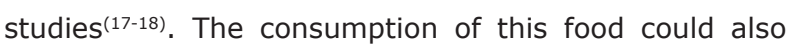
arise from the changes that are enforced by changes to the work routine, together with the habit of eating outside the home, the growth in the consumption of fast food, and also the easy availability thereof(18-19).

However, among the men the association was the inverse of that for women, with longer work hours being associated to a lower intake of fried foods. This result matches what is commonly found in specialised literature(17-18). It is possible that, for the men in this sample, the most appropriate nutrition (with lower consumption of fried foods) is a reflection of the feminine care that they receive at home. There are no records of this association in specialised literature. Let's suppose that feminine domestic work, which includes house care and also family care ${ }^{(1,3,8,19-20)}$, favours the quality of the food of these workers who are subjected to long hours of professional work. This behaviour pattern, without a shadow of doubt, warrants qualitative studies which could help to understand this relationship'.

The lack of the practice of physical exercise as leisure and also inappropriate nutrition may have been reflected in the high percentages of cases of overweight or obesity in the group, particularly among women, with the results being similar to those described in another study on nursing professionals ${ }^{(15)}$. In addition, some studies $^{(20-22)}$ consider other important factors in relation to overweight and obesity in the female group: the age bracket of the population, characterised in this study as being of middle age, which generates an impact on the metabolism(21), the condition of already having borne children $^{(20)}$, marital status(22) and hormonal phenomena such as the climacteric and the menopause ${ }^{(21)}$.

In the years leading up to the menopause, women tend to gain an extra $0.8 \mathrm{~kg} / \mathrm{year}$, and after the menopause this rise may correspond to $20 \%$ of total bodily fat ${ }^{(21)}$. However, the greatest proneness to weight gain after the menopause seems not to be due only to lack of oestrogen, but mainly the ingestion of food with energy content in excess of the needs of women in this age bracket, through the slowing of basal metabolism and also the greater likelihood of sedentarism, arising from the aging process itself.

In the two groups studied, there was no significant association between smoking and the working hours. This aspect can be related to the high educational level of the groups as studied here (all with at least a University Degree) and also their awareness of the harm caused by cigarettes, together with anti-smoking campaigns that have been massive over the last few years in Brazil, and also the prohibition of smoking in closed places (23).

The relation between short periods of sleep and long professional hours among nurses has already been seen in other studies ${ }^{(1,3)}$ which assign this result to the working hours and also the unavailability of sufficient days for days off and rest. The results could also have been influenced by the dedication to domestic chores ${ }^{(1)}$ in terms of less available time for rest.

In Brazilian culture, the consumption of coffee is normal, especially in work environments, as a form of social interaction. It has been observed that women with long stints of professional or total work hours tend to show an exaggerated consumption of coffee, a phenomenon which could be explained by the properties of caffeine which provides energy to deal with the daily 
activities in a satisfactory manner. The consumption of coffee, in moderate doses, could favour cognitive and psychomotor development, which is also necessary to be able to work long hours in a labour environment that needs maximum attention with a minimum of errors ${ }^{(24)}$. However, high doses could cause negative experiences in the users, such as tachycardia, palpitations, insomnia and anxiety ${ }^{(24)}$.

Despite the importance and the scope of the present study among nurses, some limitations must be mentioned here, including the sectional design of the study, which does not allow the establishment of time relationships between the behaviour patterns as assessed and working hours. In addition, the confidence intervals with low precision could have been affected by the size of the male population, which in many cases has not allowed the establishment of statistical associations, even though there has been the observation of high punctual association estimates. The male nurses are characterised as an unusual group of workers, when it comes to working hours, and this means that the generalisation of the findings of this study shall be made with caution. However, it is possible that in other professions aspects of long work hours have a similar influence on health-related behaviour patterns, as previously discussed.

\section{Conclusion}

The results revealed long work hours among both male and female nurses. Here we highlight the association between professional and total work hours and health-related behaviour patterns in the female group, which can be a result of the accumulation of functions both in private and professional life, which can lead to greater exposure to factors presenting a risk to health, and also less time for health care. Thus, it is suggested that people who are subjected to long work hours, with strong dedication to professional and domestic work, have less time available and also less motivation for self-care. Therefore, the consideration of types of work hours in the studies which assess health aspects, self-care and care provided to others is particularly relevant in the context of nursing workers, particularly in the female group, due to domestic work overload.

In short, the results stress the need for actions to promote health among nurses, within the context of public hospitals, and also the importance of studies that assess the impact of long work hours on workers' health. In addition, studies of this nature shall be encouraged, deepened and publicised, so that they may be foundations for the enactment of legislation which favours the general health of workers and also the care that is provided.

\section{References}

1. Silva AA, Rotenberg $L$, Fischer FM. Jornadas de trabalho na enfermagem: entre necessidades individuais e condições de trabalho. Rev Saúde Pública. [periódico na Internet]. 2011 [acesso 5 jun 2012];45(6);111726. Disponível em: http://www.scielo.br/pdf/rsp/v45 n6/2314.pdf.

2. Elias MA, Navarro VL. The relation between work, health and living conditions: negativity and positivity in nursing work at a teaching hospital. Rev. Latino-Am. Enfermagem. 2006;14(4):517-25.

3. Portela LF, Rotenberg L, Wasissmann W. Health, sleep and lack of time: relations to domestic and paid work in nurses. Rev Saúde Pública. 2005;39(5):802-8.

4. Shields $M$. Long working hours and health. Health Reports Autumn. 1999;11(2):33-48.

5. Silva AP, Souza JMP, F Borges FNS, Fischer FM. Health-related quality of life and working conditions among nursing providers. Rev Saúde Pública. 2010;44(4):718-25.

6. Spuergeon A, Harrington JM, Cooper CL. Health and safety problems associated with long working hours: a review of the current position. Occup Environm Med. 1997; 54:367-75.

7. Decreto no 94.406, de 08 de junho de 1987 (BR). Dispõe sobre a Regulamentação da Lei no 7.498, de 25 de junho de 1986, que dispõe sobre o exercício da Enfermagem, e dá outras providências. Diário Oficial da União [periódico na Internet]. [acesso 30 abr 2012]. Disponível em: http://www.coren-ba.com.br/ index. php ? view $=$ article $\&$ catid $=23 \% 3$ Adecretos $\& i d=1$ 02\%3Adecreto-no-94406\&format=pdf\&option =com content\&Itemid $=56$.

8. Rotenberg L, Portela LF, Banks B, Griep RH, Fischer FM, Landsbergis P. A gender approach to work ability and its relationship to professional and domestic work hours among nursing personnel. Appl Ergonomics. 2008;39.646-652.

9. Grosch JW, Caruso CC, Rosa RR, Sauter SC. [Long Hours of Work in the U.S.: Associations With Demographic and Organizational Characteristics, Psychosocial Working Conditions, and Health]. Am J Industr Med. 2006; 49:943-952. 
10. Motulsky H. Instituitve Viostatistic. Oxford: Oxford University Press; 1995. 386 p.

11. Bruschini MCA. Trabalho e Gênero no Brasil nos últimos dez anos. Cad Pesqui. [periódico na Internet].2005 [acesso 25 jun 2012];37(32). Disponível em: http:// www.scielo.br/pdf/cp/v37n132/a0337132.pdf.

12. Padilha MICS, Vafhetti HH, Brodersen,G. Gênero e Enfermagem:uma análise reflexiva. Rev Enferm UERJ. [periódico na Internet]. 2006 [acesso 25 jun 2012]; 14(2):292-300. Disponível em: http://repositorio.furg. br: 8080/jspui/bitstream/1/1572/1/G\%C3\%AAnero\%20 e\%20enfermagem-\%20uma\%20an\%C3\%A1lise\%20 reflexiva.pdf.

13. Baggio MA, Formaggio FM. Trabalho, Cotidiano e o ProfissionaldeEnfermagem: osignificado dodescuidadode si. Cogitare Enferm. [periódico na Internet]. 2008 [acesso 26 jun 2012];jan/mar;13(1):67-74. Disponível em: http://ojs.c3sl.ufpr.br/ojs2/index.php/cogitare/article/ viewFile/11954/8435.

14. Krantz G, Ostergan PO. [Double exposure. The combined impact of domestic responsibilites and job strain on common symptoms in employed Swedish women]. Eur J Public Health. 2001;11(4):413-9.Inglês.

15. Hibbard JH, Pope CR. Effect of domestic and occupational roles on morbidity and mortaliy. Soc Sci Med. 1991;32(7):805-11. Inglês.

16. Nascimento LC, Mendes IJM. Health profile of workers in a Teaching Health Center. Rev. Latino-Am. Enfermagem. jul-ago 2002;10(4):502-8.

17. Maia CO, Goldmeier S, Moraes MA, Boaz MB, Azzolin $\mathrm{K}$. Fatores de risco modificáveis para doença arterial coronariana nos trabalhadores de enfermagem. Acta Paul Enferm. [periódico na Internet]. 2007 [acesso 28 jun 2012], 2007;20(2):138-42. Disponível em: http:// www.scielo.br/pdf/ape/v20n2/a05v20n2.pdf.

18. Silva RM, Back CLC, Magnago TSBS, Carmagnani MIS, Tavares JP, Prestes FC. Trabalho noturno e a repercussão na saúde dos Enfermeiros. Esc Anna Nery [internet]. 2011; [acesso 30 jun 2012]; 15 (2):270-6. Disponível em: http://www.scielo.br/pdf/ean/v15n2/ v15n2a08.pdf.

19. Palma RFM, Barbieri P, Damião R, Polleto J, Chaim R, Gimeno SG, et al.Fatores associados ao consumo de frutas, verduras e legumes em Nipo-Brasileiros. Rev Bras Epidemiol. [periódico na Internet]. 2009 [acesso 24 jun 2012];12(3);436/45. Disponível em :http:// www.scielosp.org/pdf/rbepid/v12n3/12.pdf.

20. Fonseca MJM, Chor D, Valente J G. Hábitos alimentares entre funcionários de banco estatal: padrão de consumo alimentar. Cad Saúde Pública. [periódico na Internet]. 1999 [acesso 6 jul 2012],15(1);29-39. Disponível em: http://www.scielosp.org/scielo.php?script=sci_arttext \&pid=S0102-311X1999000100004\&Ing=pt.

21. De Lorenzi DRS, Basso E, Fagundes PO, Sacioloto B. Prevalência de sobrepeso e obesidade no climatério. Rev Bras Ginecol Obstet. [periódico na Internet]. 2005 [acesso 25 jun 2012];27(8):479-84.Disponível em: http://www.scielo.br/pdf/rbgo/v27n8/26759.pdf.

22. Andreto LM, Souza AI, Figueirosa JN, Filho JEC. Fatores associados ao ganho ponderal excessivo em gestantes atendidas em um serviço público de pré-natal na cidade de Recife, Pernambuco, Brasil. Cad Saúde Pública. [periódico na Internet]. 2006 [acessado em 26 jun 2012]; 22(11): 2401-9. Disponível em: http://www. scielo.br/pdf/csp/v22n11/14.pdf.

23. Echer IC, Correa APA, Lucena, AF, Ferreia SAL, Knorst MM. Prevalence of Smoking Among Employees of a University Hospital. Rev. Latino-Am. Enfermagem. [periódico na Internet]. jan-fev 2011;19(1):179-86.

24. Alves R, Casal S, Oliveira B. Benefícios do café na saúde: mito ou realidade?. Quím Nova. 2009;32(8):2169-80. 